Turkish Psychological Counseling and Guidance Journal

Türk Psikolojik Danışma ve Rehberlik Dergisi
Terzi İlhan \& Işı1k (2021)

Vol: 11 Number: 63 Page: 543-566 ISSN: 1302-1370

\title{
A Validity and Reliability Study on the Development of Marital Attachment Injuries Scale
}

\author{
Evlilikte Bağlanma Yaralanmaları Ölçeği Gelistirme, Geģerlike ve Güvenirlike Çalıs̆ması
}

\section{Sare Terzi İlhan $\odot$, Şerife Işık}

Authors Information
Sare Terzi İlhan
Research Assistant, Amasya
University, Amasya, Turkey
sare.terzi@amasya.edu.tr
Şerife Iş1k
Professor, Gazi University, Ankara,

Professor, Gazi University, Ankara, Turkeyserife7403@gmail.com

\begin{abstract}
This study aims at developing a valid and reliable scale to identify the level of attachment injuries of married individuals. This study, which has adopted a survey model, is a descriptive study that has been designed to reveal the construct of the concept of attachment injury and to develop a data collection tool to measure the concept. In this direction, the steps of a scale development process were followed, and a pool of items was first developed accordingly. Explanatory factor analysis, as well as validity and reliability study, was conducted with the data obtained from 287 participants, 203 of whom were female and 84 of whom were male. Then a confirmatory factor analysis was carried out with the data gathered from 253 participants, 156 of whom were female and 79 of whom were male. At the end of the analyses came out a valid and reliable data collection tool which has 17 items in total and is composed of two dimensions, which are "insecure attachment" and "trauma" to identify the level of attachment injuries of married individuals.
\end{abstract}

\begin{tabular}{|c|c|}
\hline Article Information & ÖZET \\
\hline $\begin{array}{l}\text { Keywords } \\
\text { Attachment Injuries } \\
\text { Marriage } \\
\text { Attachment } \\
\text { Scale Development } \\
\text { Anahtar Kelimeler } \\
\text { Bağlanma Yaralanmalar1 } \\
\text { Evlilik } \\
\text { Bağlanma } \\
\text { Ölçek Geliştirme } \\
\text { Article History } \\
\text { Received: } 06 / 04 / 2021 \\
\text { Revision: } 21 / 11 / 2021 \\
\text { Accepted: } 10 / 12 / 2021\end{array}$ & 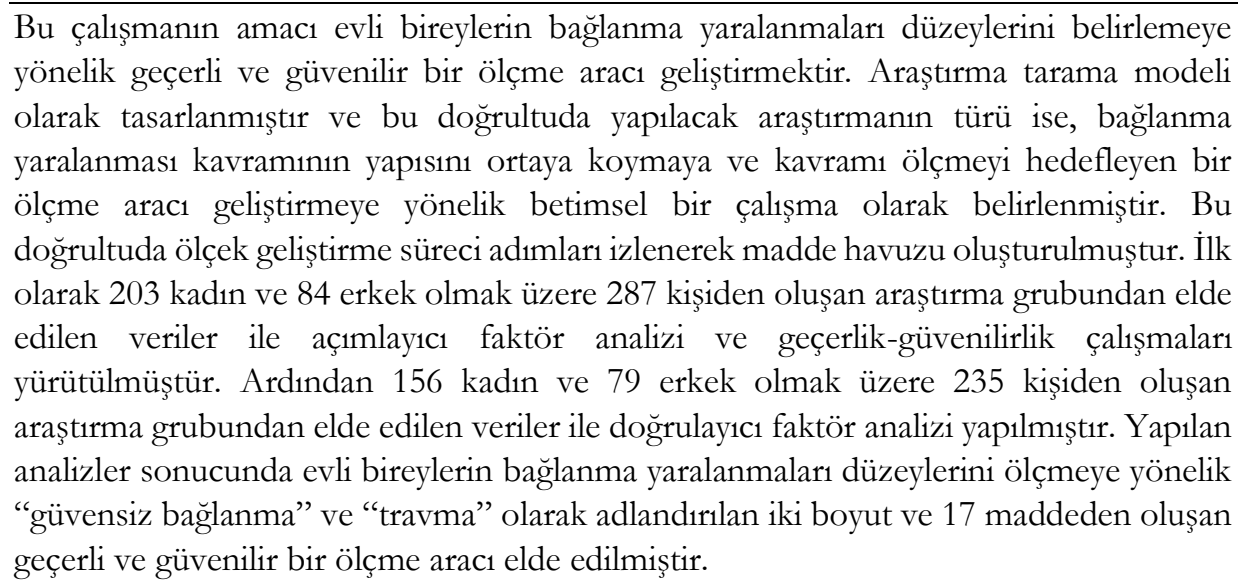 \\
\hline
\end{tabular}

Cite this article as: Terzi İlhan, S., \& Işık, Ş. (2021). A validity and reliability study on the development of marital attachment injuries scale. Turkish Psychological Counseling and Guidance Journal, 11(63), 543-566.

Ethical Statement: For this research, the permissions were obtained from Amasya University Scientific Research and Ethical Review Board (Referans: 19642/15.09.2020) and the privacy of the participants was protected in the study. 


\section{INTRODUCTION}

The term of marriage and family therapy was outlined in addressing the concepts of attachment injuries, attachment theory, and approaching this theory as a trauma theory, all of which are included in the field of psychological counseling and psychology (Johnson, 1996; Millikin, 2000). The theoretical infrastructure of the concept is established by the theory of attachment in children and adults, emotionfocused couple therapy, and the experiences gained through clinical practices (Millikin, 2000). Attachment injury, which is accepted to be a novel concept in the field of mental health, appears when one of the couples says or does something that damages the very nature of attachment (Johnson, 1996).

Johnson (1996) describes attachment injuries as traumatic events that harm the nature of attachment and that affect the nature of a relationship that is being lived actively at the moment. The incident that ascertains the attachment injuries works as a warning system or an alarm that gives out a message implying that it is not possible to trust the partner anymore about providing security and comfort. The injured partner experiences a decrease in the level of trust in the partner and might indirectly decide that the partner cannot provide security and comfort (Millikin, 2000).

When one of the couples having a romantic relationship needs the support or help of his/her partner, and to feel that his/her partner is there for him/her, but feels that s/he is neglected by his/her partner or the partner does not make him/her feel that $\mathrm{s} /$ he is there for him/her, then s/he loses the basic feeling of trust for the partner (Johnson, 1996). It is known that attachment injuries mostly occur when one goes through a transition period in life such as retirement, moving to a new place or changing job; a loss such as the death of a close one, loss of status or miscarriage; a physical danger such as a chronic illness and times of ambiguity (Johnson et al., 2001). Although many couples who are living a romantic relationship or who are married have times of resentment, all couples do not experience such traumatic injuries (Johnson, 1996). Moreover, all problems experienced by couples about their relationships cannot be called attachment injuries. Two couples can simply have similar experiences or go through similar incidents. One couple can overcome these experiences with very little problem, the other couple can face an important relationship trauma or attachment injury at the end of such life experiences (Millikin, 2000).

It is seen that attachment injury is an important concept that affects romantic relationships and marriages negatively, and it diminishes the trust and satisfaction in a relationship. It is a concept that comes out in practices of especially couple and marriage therapy as a factor that hinders secure attachment in relationships as well as trust and intimacy between partners, and it turns out to be a problem or difficulty that should be intervened.

It is known that experiences of attachment injuries that refer to a traumatic loss of trust about feeling that the partner is available and accessible in case of a critical need as well as to the damage of secure attachment (Johnson, 1996; Millikin, 2000) have a great impact on the level of trust between partners (Millikin, 2000), intimacy between the partners (Johnson, 1996) and couple satisfaction (Halchuk et al., 2010). The literature review shows that there is a limited number of studies both at the national and international level about attachment injuries that hurt the relationship between the partners, and that cannot be treated or that can repeat even after a couple of therapy is conducted if it is not handled directly (Johnson, 1996; Millikin, 2000).

When the studies on attachment injuries in the literature are reviewed, it is noticed that attachment injury has been explored in clinical practices of emotion-focused couple therapy Johnson, 1996; Millikin, 2000; 
Johnson et al., 2001), and Attachment Injury Resolution Model has been developed to treat attachment injuries within the scope of clinical practice studies (Millikin, 2000), validity and practicality of this model has been tested in various studies with various samples (Johnson et al., 2001; Makinen, 2004; Naaman et al., 2005; Makinen and Johnson, 2006; Halchuk et al., 2010). Besides, there are qualitative studies that aim at understanding and examining the experiences of people who have experienced attachment injuries in their relationships (Pelling, 2003; Pelling and Arvay - Buchanan, 2004). However, the researcher could not come across a quantitative study on the concept of attachment injury in the literature. There is a need for data collection tool to be used in quantitative studies to reveal the variables related to the attachment injuries that hurt people's marriage/relationship adjustment and satisfaction and harm the feeling of trust between partners, to identify the qualities of individuals that experience attachment injuries, to test the theoretical models to be developed to the concept of attachment injury based on this knowledge, to find out whether individuals experience attachment injuries in their relationships or not, to develop intervention plans to treat attachment injuries. However, the literature review shows that there is not a scale for attachment injuries whose validity and reliability have been tested and proved either in national literature or in the international one. Terzi and Özbay (2016) have conducted a study to develop a scale to identify attachment injuries in romantic relationships. A scale having acceptable values in social and behavioral sciences has been developed at the end of the explanatory factor analysis conducted within the scope of this study. However, it is seen that only an explanatory factor analysis has been conducted in this study. The construct of the Attachment Injuries in Romantic Relationships Scale (AIRRS) could not be proved with the confirmatory factor analysis as well as validity and reliability analyses. It has been decided after receiving expert views to develop a new valid and reliable scale to measure the concept of attachment injuries. In this direction, this study aims at developing a valid and reliable data collection tool to identify the level of attachment injuries in married individuals.

\section{METHOD}

This study has been designed as a survey model. Survey models are approaches that try to describe a current situation as it is (Karasar, 2009). In this direction, the type of this study is a descriptive one for developing a data collection tool that aims to reveal the theoretical construct of the concept of attachment injury and measure this structure. Descriptive studies are intended to understand and define a current situation (Erkuş, 2011).

\section{Study Sample}

There are two different study samples in this study. Both of the samples were formed taking the advantage of purposive sampling method, which is based on the idea of choosing the sample among people possessing specific restrictive qualities in line with the study aim (Erkuş, 2011; Frankel et al., 2012). This study has been in Turkey and all of the participants are from Turkey.

Within the framework of explanatory factor analysis (EFA) and validity-reliability analyses, the first study sample was composed of 287 people, $203(\% 70,7)$ of whom were female and $84(\% 29,3)$ of whom were male, all of whom had been married for at least a year, were voluntarily willing to participate in the study and mentioned a critical incident that negatively affected their marriage. The information about the first study sample included in the study within the framework of developing the Marital Attachment Injuries Scale (MAIS) is given in Table 1: 


\begin{tabular}{|c|c|c|c|c|c|c|c|}
\hline Variable & & $\mathrm{N}$ & $\%$ & Min & Max & $\mathrm{X}_{\text {mean }}$ & $\mathrm{Sd}$ \\
\hline \multirow{3}{*}{ Gender } & Female & 203 & 70,73 & & & & \\
\hline & Male & 84 & 29,27 & & & & \\
\hline & Total & 287 & 100 & & & & \\
\hline Age & & 287 & & 22 & 62 & 33,95 & 7,02 \\
\hline \multirow{6}{*}{$\begin{array}{l}\text { Level of } \\
\text { Education }\end{array}$} & Primary School & 0 & 0 & & & & \\
\hline & Secondary School & 6 & 2,09 & & & & \\
\hline & High School & 10 & 3,48 & & & & \\
\hline & $\begin{array}{c}\text { Associate's } \\
\text { Degree/Bachelor's } \\
\text { Degree }\end{array}$ & 158 & 55,05 & & & & \\
\hline & $\begin{array}{l}\text { Postgraduate } \\
\text { Degree }\end{array}$ & 113 & 39,38 & & & & \\
\hline & Total & 287 & 100 & & & & \\
\hline $\begin{array}{l}\text { Years of } \\
\text { Marriage }\end{array}$ & & 286 & & 1 & 43 & 8,19 & 7,53 \\
\hline \multirow{6}{*}{$\begin{array}{l}\text { Number } \\
\text { of } \\
\text { Children }\end{array}$} & None & 78 & 27,18 & & & & \\
\hline & 1 & 116 & 40,42 & & & & \\
\hline & 2 & 79 & 27,53 & & & & \\
\hline & 3 & 11 & 3,83 & & & & \\
\hline & 4 and more & 3 & 1,04 & & & & \\
\hline & Total & 287 & 100 & & & & \\
\hline
\end{tabular}

As is seen in Table 1, the participants were aged between 22 and 62, whereas the average of the participants' ages was 33,95 . Six $(\% 2,09)$ of the participants were secondary school graduates, $10(\% 3,48)$ of them were high school graduates, $158(\% 55,05)$ of them had an associate's/bachelor's degree and 113 $(\% 39,38)$ of them had a postgraduate degree. Years of marriage varied between one and 43 , while the average year of marriage was 8,19. $78(\% 27,18)$ of the participants had no child, $116(\% 40,42)$ of them had one child, $79(\% 27,53)$ of them had two children, $11(\% 3,83)$ of them had three children, three $(\% 1,04)$ of them had four or more children.

Within the framework of confirmatory factor analysis (CFA) conducted to confirm the factor construct of the scale obtained at the end of EFA and validity-reliability analyses, the second study group consisted of 235 participants, $156(\% 66,38)$ of whom were female and $79(\% 33,62)$ of whom were male, all of whom had been married for at least a year, were voluntarily willing to participate in the study and mentioned a critical incident that negatively affected their marriage. The information about the second study sample included in the study within the framework of conducting CFA is given in Table 2:

\begin{tabular}{|c|c|c|c|c|c|c|c|}
\hline Variable & & $\mathrm{N}$ & $\%$ & Min & Max & $\mathrm{X}_{\text {mean }}$ & $\overline{\mathrm{Sd}}$ \\
\hline \multirow{3}{*}{ Gender } & Female & 156 & 66,38 & & & & \\
\hline & Male & 79 & 33,62 & & & & \\
\hline & Total & 235 & 100 & & & & \\
\hline Age & & 235 & & 20 & 60 & 33,52 & 7,78 \\
\hline \multirow{4}{*}{$\begin{array}{l}\text { Level of } \\
\text { Education }\end{array}$} & Primary School & 4 & 1,70 & & & & \\
\hline & Secondary School & 3 & 1,28 & & & & \\
\hline & High School & 26 & 11,06 & & & & \\
\hline & $\begin{array}{c}\text { Associate's } \\
\text { Degree/Bachelor's } \\
\text { Degree }\end{array}$ & 116 & 49,36 & & & & \\
\hline
\end{tabular}




\begin{tabular}{|c|c|c|c|c|c|c|c|}
\hline & $\begin{array}{c}\text { Postgraduate } \\
\text { Degree }\end{array}$ & 86 & 36,60 & & & & \\
\hline & Total & 235 & 100 & & & & \\
\hline $\begin{array}{l}\text { Years of } \\
\text { Marriage }\end{array}$ & & 286 & & 1 & 42 & 9,71 & 8,39 \\
\hline \multirow{5}{*}{$\begin{array}{l}\text { Number of } \\
\text { Children }\end{array}$} & None & 46 & 19,57 & & & & \\
\hline & 1 & 83 & 35,12 & & & & \\
\hline & 2 & 83 & 35,12 & & & & \\
\hline & 3 & 23 & 10,19 & & & & \\
\hline & Total & 235 & 100 & & & & \\
\hline
\end{tabular}

Table 2 shows that the participants were aged between 20 and 60, while the average age of the participants was 33,52 . When it comes to the educational level of the participants, it is seen that four $(\% 1,70)$ of the participants were primary school graduates, three $(\% 1,28)$ of them were secondary school graduates, 26 $(\% 11,06)$ of them were high school graduate, $116(\% 49,36)$ of them had an associate's/bachelor's degree and $86(\% 36,60)$ of them had a postgraduate degree. Years of marriage varied between one and 42 , whereas the average year of marriage was $9,71.46(\% 19,57)$ of the participants had no child, $83(\% 35,12)$ of them had one child, $83(\% 35,12)$ of them had two children and $23(\% 10,19)$ of them had three children.

\section{Research and Publication Ethics Statement}

In this research, it has been observed research and publication ethics. For this research, the permissions were obtained from Amasya University Scientific Research and Ethical Review Board (Referans: $19642 / 15.09 .2020)$ and the privacy of the participants was protected in the study.

\section{Measurements}

The measurements used within the framework of this study are as below:

Personal Information Form. A Personal Information Form developed by the researcher was used in the two processes of data collection within the scope of MAIS studies. This form was intended for gathering information about participants' gender, age, level of education, profession, total monthly income, years of marriage, which marriage (in order) they were in, number of children. In both studies, the participants were asked an open-ended question, "Have you had a critical bad situation, incident, or experience that you think affects your marriage in a negative day since the day when you got married? (such as miscarriage, a chronicle/deadly illness, loss of a close person, changing job, changing the place where you live/moving.) If yes, what is it?" This question was used in this study depending on the fact that it has been stated in the literature that an attachment injury can only result from an incident experienced in the marriage relationship.

Marital Attachment Injuries Scale (MAIS). A new scale has been developed at the end of the analyses conducted within the scope of this study. The information as to the process of developing a scale and the psychometric qualities of the scale are given in the findings of this study.

Relationship Assessment Scale (RAS). RAS was developed by Hendrick (1988) and adapted into Turkish culture by Curun (2001). While the original scale is a 5 -point Likert type scale, the Turkish version is a 7-point Likert type scale, which is composed of seven items and one factor. Items 4 and 7 are reversescored. Having a high score from RSS means a high level of relationship satisfaction. Hendrick (1988) conducted Principal Components Factor Analysis to test the construct validity of RAS while developing the scale. It was found out that there was only one factor whose eigenvalue was above 1, this factor 
explained \%46 of the variance, total item correlation was between, 57 and,76. In line with the original scale, Curun (2001) concluded during the adaptation studies of the scale into Turkish that there was one factor whose eigenvalue was above 1 and the explained variance was $\% 52$. The internal consistency coefficient that was calculated to test the reliability of the scale was found to be,86. The internal consistency coefficient of RAS was found to be,914 in this study.

The Marital Disaffection Scale (MDS). MDS was developed by Kayser (1996) and adapted into Turkish culture by Çelik (2013). Both the original form and adapted version of MDS are a 4-point Likert scale, while they consist of 21 items and one factor. Items 1, 3, 5, 6, 7, 8, 9, 11, 14, 16 and 21 are reversescored. The score of marital disaffection is obtained by adding all the scores gathered from MDS, and having a high score means a high level of marital disaffection. The lowest score to be obtained from the scale is 21 , whereas the highest score is 84 . The internal consistency coefficient of the original scale is, 97 . The explained variance of the Turkish version is $\% 35,85$, whereas internal consistency is , 89 . The internal consistency coefficient of MDS was found to be ,954 in this study.

\section{Analysis of Data}

EFA and validity-reliability analyses, as well as CFA, were conducted while developing MAIS. EFA and validity reliability was analyzed using SPSS 21.0, whereas CFA was analyzed using LISREL.

\section{Process Steps}

The steps that were followed within the scope of developing MAIS are given in Figure 1 below.

Each step of developing MAIS is explained below respectively:

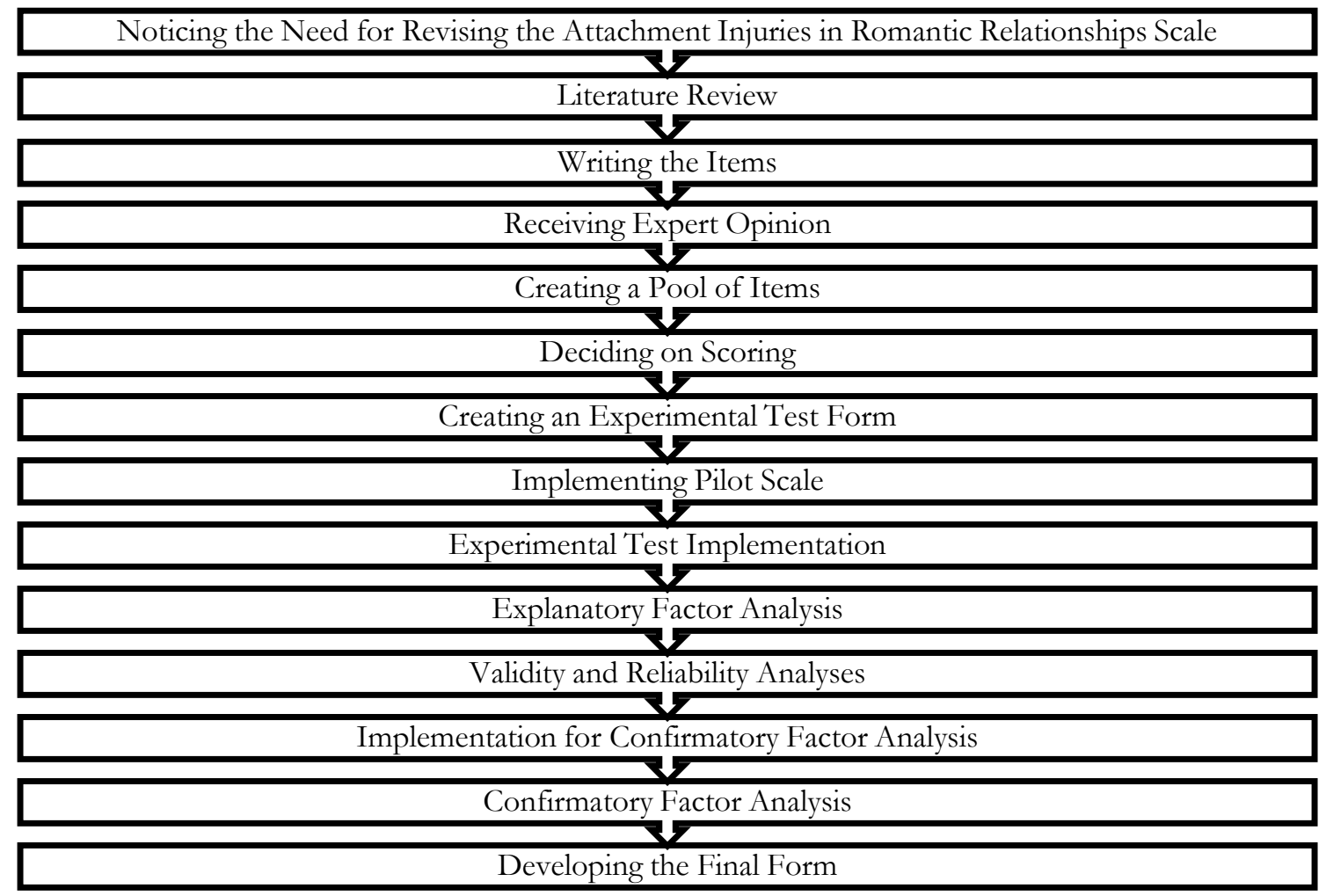

Figure 1. Process Steps of Developing MAIS 
Each step of developing MAIS is explained below respectively:

Feeling the Need to Revise Attachment Injuries in Romantic Relationships Scale (AIRRS): Terzi and Özbay (2016) conducted a study to develop a scale to measure the attachment injuries of married individuals, and the psychometric qualities of the scale were put forth. However, CFA and validityreliability analyses for AIRRS were not done in this study. The qualities of this scale were examined and three experts, one studying in the field of Psychological Counselling and Guidance, the other studying in the field of Assessment and Evaluation and the last one studying in the field of Psychology and carrying out studies on romantic relationships, were asked their views and as a result, it was decided to review and revise the scale of AIRRS developed by Terzi and Özbay (2016).

Literature Review. After deciding on the need to revise AIRRS, the literature on attachment, attachment theory, emotion-focused therapy, and attachment injuries was reviewed within the framework of the studies to develop a scale.

Writing the Items: After reviewing the literature, items were written to measure the attachment injuries of married individuals, and the items included in AIRRS having a factor load over,70 were taken. Thus, there were 75 items for the scale to measure the attachment injuries of married individuals. The information as to the 75 items are given in Table 3:

\section{Table 3. Items for Measuring the Attachment Injuries of Married Individuals}

1. Bu olaydan sonra eşime eskisi kadar güvenemiyorum.

"They are considered traumatic in

2. Bu olaydan sonra kendimi eşime eskisi kadar yakın hissedemiyorum. that they induce overwhelming fear

3. Bu olaydan eşime olan güven duygumu sarstı.

and helplessness and, if not

4. Bu olaydan sonra eşimle birbirimizden uzaklaştığımızı düșünüyorum. resolved and healed, severely limit trust and intimacy." Johnson, 1996, p. 268)

"The sense of basic trust in the partner is shattered."." (Johnson, 1996, p. 269)
5. Bu olaydan sonra, eşim için her şeyi göze alamayacağımı düşünüyorum.
6. Ne olursa olsun, eşim için yapamayacağım şey yoktur.
7. Gerekirse eșim için canımı dahi veririm.
8. Tekrar kırılma ihtimalim olsa bile, eşime yine aynı şekilde güvenirim.
9. Evliliğimizin devam etmesi için yapamayacağım şey yoktur.

10. Eşimle yaşadığımız bu olay olur olmaz zamanlarda aklıma geliyor.

11. Gün içerisinde herhangi bir sıradan olay ya da nesne bana o olay1 hatırlatabiliyor.

12. Eşimle yaşadığımız bu olay aklımdan hiç çıkmıyor.

13. Bu olayı tekrar tekrar hatırlamak beni huzursuz ediyor.

14. Bu olayı hatırlamaktan korkuyorum.

15. Eşimle benzer bir olay yaşamaktan korkuyorum.

16. Yaşadığımız bu olayı hatırlama ihtimalim beni tedirgin ediyor.

17. Eșimle yașadığımız bu olaya dair hiçbir șey hissetmiyorum.

18. Bu olay aklıma geldiğinde duygularım yokmuş gibi hissediyorum.

19. Eşimle ilişkimize dair hiçbir şey hissetmiyorum.

20. Bu olaydan sonra ilişkimizin doğasının değiştiğini düşünüyorum

21. Bu olaydan sonra eşimle birbirimize karşı davranışlarımız değişti.

22. Eșime ihtiyaç duyduğum her an ulaşabileceğimi biliyorum.
"These incidents, which have been perhaps referred to before in previous sessions as a general hurt, then arise in the manner of a traumatic flashback and block engagement and risk-taking." (Johnson, 1996, p. 268)

"Injured partners describe how images and memories of these injuries are easily evoked and create a hypervigilance to possible reoccurrences or reminders." (Johnson, 1996 p. 268)

"They also speak, in the way that echoes the general trauma literature, of numbing Themselves in interactions with their spouse." Johnson, 1996, p. 268) 
23. Zor bir durumla karşılaştı̆ımda eşimin benim yanımda olacağından "They often occurred at particularly eminim.

24. Eşim her ihtiyaç duyduğumda yanımdadır. critical moments of need when a

25. Zor durumda isem, eşim iki eli kanda olsa dahi gelir. person was particularly vulnerable.

26. Ona ihtiyaç duyduğumda, eşime ulaşamam.

27. Ne zaman yardımına ihtiyacım olsa eşim ortada yoktur. These events may become a

28. Bu olaydan sonra evliliğimize olan inancım sarsildi. touchstone, an incident that, for

29. Bu olaydan sonra evliliğimize olan güvenimi yitirdim. them, defines the security of the relationship. The attachment injury event serves as an alarm, a warning system that sends the message that the other cannot be trusted to provide security and comfort." (Millikin, 2000, p. 2- 3)

30. Bu olaydan sonra eşime psikolojik olarak ulaşamadığımı hissediyorum.

"An attachment injury was hypothetically defined as clients who entered therapy and became

31. Ne zaman ihtiyaç duysam eşim sanki ortadan kaybolur. stuck on one significant episode in the relationship that marked a disruption in the level of trust, security, responsiveness, and accessibility of partners (Johnson, Personal Communication, 1998)" (Millikin, 2000, p. 26).

32. İlişkimiz bu olayda takılı kaldı gibi hissediyorum. The definition of an attachment

33. Yaşadığımız bu olay ilişkimizi derinden etkiledi. injury was when one partner betrayed or broke the trust of the other in a specific incident and that incident became a clinically recurring theme and stuck point of task resolution. (Millikin, 2000, p.38)"

34. Yaşadığımız bu olayda eşim beni yapayalnız bıraktı. "The female partner in Couple 3 35. Yaşadığımız bu olay eşimle aramıza mesafe koydu. reported a specific event when she was having a miscarriage and her partner refused to come home from work to help her. She remarked that the miscarriage frightened her and she called for comfort. His refusal to come home marked a feeling of distance between them." (Millikin, 2000, p.40)"

36. Yaşadığımız bu olay beni adeta yıktı.

"I was devastated that he was backing out on a very important promise." (Millikin, 2000, p.40)"

37. Bu olaydan sonra eşimle iletişimimiz çok azaldı. "These couples relate to one

38. Eşimle iletişim kurduğumuzda genellikle tartışıyoruz. another in limited ways, often

39. Bu olaydan sonra ilişkimizde bir kısır döngüye takılıp kaldığımı düșünüyorum.

40. Eşimle çoğu zaman öfke dolu konuşmalarımız oluyor. through defensiveness, reactivity, anger, indifference and rigid attack and defend cycles." (Millikin, 2000, p.55)

41. Yaşadığımız bu olay benim için yeni yaşanmış gibi canlı ve etkili. "often reemerge in an alive and intensely emotional manner" Johnson, Makinen \& Millikin, 2001) 
"This incident sometimes appeared, at first glance, to be relatively insignificant, but it evoked compelling, constricted emotional responses and interaction patterns, such as blame/defend, that blocked further progress." (Johnson, Makinen \& Millikin, 2001)

44. Bu olaydan sonra eşimle birbirimize yabancılaştık.

"They spoke of isolation and

45. Yaşadığımız bu olayda eşim tarafindan terk edilmiş gibi hissettim

46. Bir daha asla eşime eskisi kadar güvenemeyeceğim.

47. Eşimle bir daha asla eskisi gibi olamayacağımızı düşünüyorum.

48. Eşimin bir daha bana bu şekilde davranmasına firsat vermeyeceğim.

49. Eşim için önemli olduğumu hissetmiyorum.

50. Eşimle bir daha eskisi gibi olamayız.

51. Eşimin hayatında önceliğim olduğunu düşünmüyorum

52. Evliliğe çocuğum için katlanıyorum.

53. Eşimin bana değer verdiğini düşünmüyorum.

54. Eşimle paylaştığım şeyler azald1.

55. Yaşadığımız sorunlardan dolayı eşimle birbirimizden oldukça uzaklaştık.

56. Bu olaydan/olaylardan sonra, eşime olan ilgim azald1.

57. Bu olayla/olaylarla ilgili olarak eşim, beni anlamak için yeterince çaba göstermiyor

58. Yaşadıklarımız evliliğimizde onarılamaz bir yara açtı.

59. Eşimin benimle paylaştı̆̆1 şeyler azald1.

60. Evliliğimizin düzeleceğine dair umudum yok.

61. Eşimle daha az vakit geçiriyorum

62. Evliliğe ailem üzülmesin diye katlanıyorum.

63. Eşimin davranışları/yaptıkları ile daha az ilgileniyorum.

64. Olay1/olaylar1 hatırlamaktan korkuyorum.

65. Eşim tarafindan tekrar incitilmekten korkuyorum.

66. Yaşanan bu olayı/olayları hatırlamamaya çalışıyorum.

67. Bana bu olayı hatırlatan rüyalar görüyorum.

68. Yaşadığımız bu olay ile ilgili kâbuslar görüyorum.

69. Kendimi gergin ve tedirgin hissediyorum.

70. Eşime karşı öfke patlamaları yaşıyorum.

71. Bu olaydan sonra sağllğım bozuldu.

72. Uyku problemleri yaşıyorum.

73. Görünür bir neden yokken ağlama krizleri yaşıyorum.

74. Bu olaydan sonra kişilerarası ilişkilerimin bozulduğunu düşünüyorum.

75. Eşimle iletişim sorunları yaşıyoruz.

The item was written depending on the Scale for the Causes of Separation

Receiving Expert Opinion: An AIRRS Expert Opinion Form was developed to receive opinions from experts as to the 75 items designed to measure the attachment injuries of married individuals. AIRRS Expert Opinion Form included an instruction, a short informatory text on the concept of attachment injury, and the item pool consisting of 75 items in total. AIRRS Expert Opinion Form was sent to nine experts. The experts were asked to evaluate each item by the phrases, which are "Appropriate", "Partly 
Appropriate" and "Not Appropriate" within the framework of the questions of "Can the item represent the quality to be measured?", "Can the item be understood by the target group easily?" and "Is the item expressed enough?"

Creating the Item Pool: Upon doing the necessary changes and amendments in line with the expert opinions, the number of items decreased to 42 and the name, Attachment Injuries in Romantic Relationships Scale, was changed into "Marital Attachment Injuries Scale (MAIS)." MAIS item pool having 42 items in total was reviewed by an academician studying in the field of psychometry, and expressions of items were amended as suggested. MAIS item pool consisting of 42 items is given in Table 4:

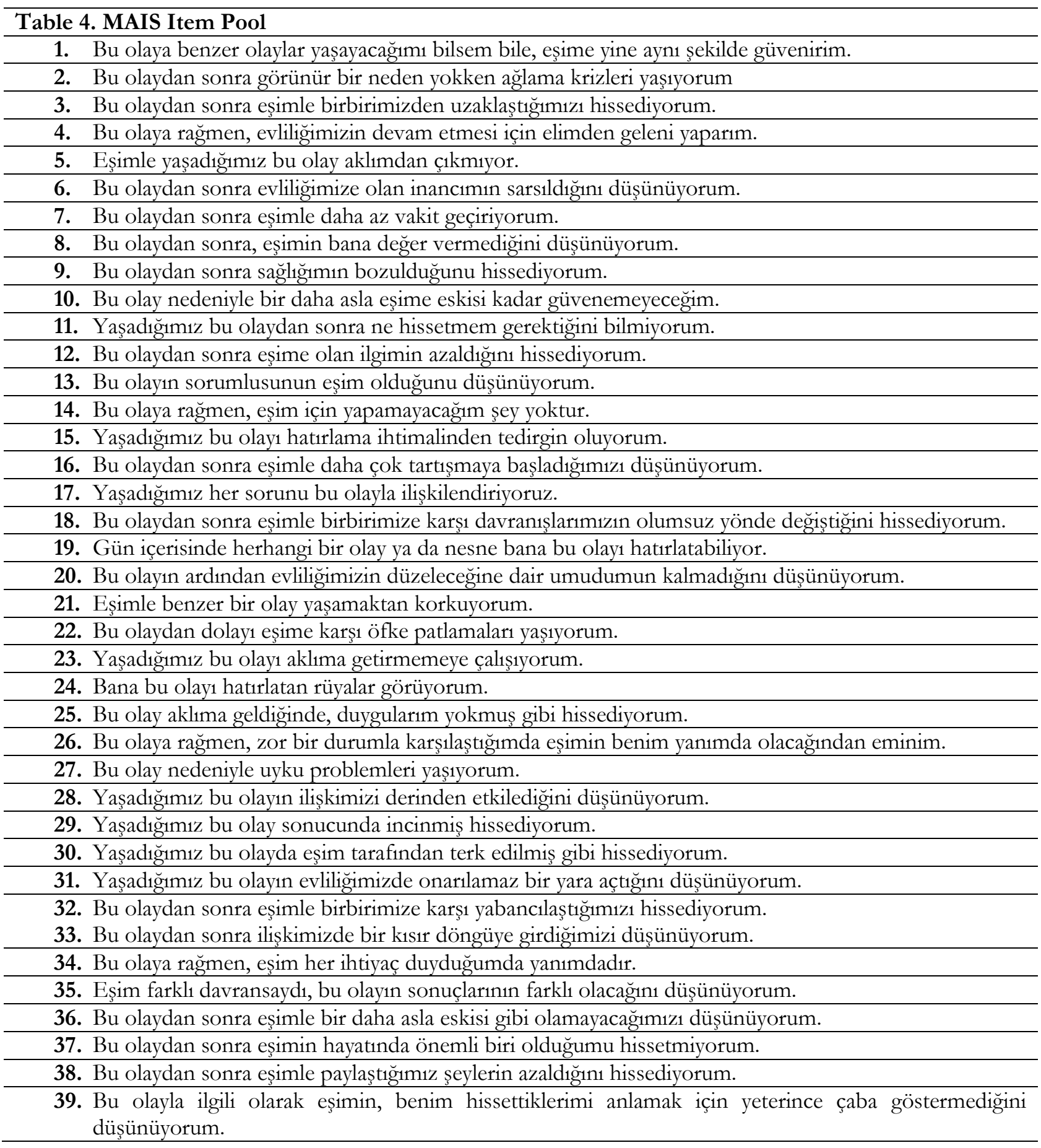


40. Yaşadığımız bu olayın, benim için, yeni yaşanmış gibi canlı ve etkili olduğunu düşünüyorum.

41. Bu olaydan sonra, eşim tarafindan tekrar incitilmekten korkuyorum.

42. Bu olay nedeniyle kendimi gergin ve tedirgin hissediyorum.

Deciding on the Scoring: Likert-type scales are scales in which individuals have presented with a set of statements and are asked to specify if they agree or disagree with these statements (Erkuş, 2012, p.78). As the participants were going to be asked if they agree or disagree with the statements they are presented in this scale, it was decided to develop a Likert-type scale. The points in Likert-type scales can be 3, 5, 7, 9, or 11 (Tavşancıl, 2010, p.145). Considering this information, a 5-point type was used in this scale. In AIMS, 1 refers to "Strongly Disagree", 2 "Disagree", 3 "Partly Agree", 4 "Agree” and 5 "Strongly Agree."

Constructing the Experimental Test Form: After establishing the item pool and deciding on the scoring, the items were converted into a scale form. It is stated in the literature that symptoms showing that an individual has experienced an attachment injury appear, in other words, attachment injuries occur only when married individuals experience an incident that they perceive as bad in their marriage (Johnson et al., 2001). An open-ended question was written for that purpose. A test form was constructed by including the open-ended question, an instruction, and scale items respectively.

Pilot Implementation: After constructing the test form of MAIS, the final whole form to be implemented was generated by including the Personal Information Form developed by the researcher, RAS (Curun, 2001) and MDS (Çelik, 2013), which were decided to be used for criterion-related validity respectively. Before conducting a large-scale implementation, the first pilot implementation (pretesting) was carried out by the researcher using implementing the form face-to-face with six participants, three of whom were female and three of whom were male, to evaluate issues such as possible misspelling, clarity of instruction and items, identifying an average duration to complete the form. After the pilot implementation, it was seen that the participants could not see the open-ended question located at the beginning of the MAIS Test Form and so did not answer this question, so it was decided to include the open-ended question at the end of the personal information form. Moreover, spelling mistakes in the implementation form were corrected and the average duration to implement the form was found to be 8-10 minutes.

Experimental Test Implementation: The scale that was finalized after the pilot implementation was copied and converted into an online scale on Google Forms. The scale was filled in by 750 people as hard copy or online. The data gathered from 750 people were arranged in a way to include the participants who stated that they had experienced an incident affecting their marriage negatively as an answer to the open-ended question at the end of the Personal Information Form and exclude those who didn't state that they had experienced an incident affecting their marriage negatively. After this arrangement, data from 312 participants were included in the study. Among these 309 data, it was noticed that four of them were completed randomly by the participants and so they were excluded. After these steps, 309 data sets were obtained to analyze via SPSS 21.0 package program.

Explanatory Factor Analysis (EFA): As EFA is a method of analysis that is sensitive to sample, it is necessary to prepare the data for EFA after the data entry (Erkuş, 2012; Tabacknick and Fidell, 2015, p. 617; Tavşanc1l, 2010). The suggested steps to follow to prepare the data for analysis are as below (Erkuş, 2012; Tabacknick and Fidell, 2015, p. 617-619): Checking the possibility of false data entry, amending the points of reverse items, amending the missing/lacking data and sorting out outliers. In this line, first of all, the data were checked and false data entry cases were corrected. Then the points of the reverse items 
in the scale which are 1, 4, 14, 26, and 34 were amended. As there was no missing/lacking value in the data set, the next step was conducted to sort out outliers. 22 data, which were noticed to be an outlier, were excluded from the data set, and so there were 287 data for EFA. After preparing the data, EFA was conducted with 287 data.

Validity - Reliability Analyses: To prove the validity and reliability of the scale as to the construct obtained at the end of EFA, total item correlation, comparison between upper and lower groups of \%27, criterion-related validity, and Cronbach alfa reliability coefficient were calculated. SPSS 21.0 package program was used to carry out these calculations.

Confirmatory Factor Analysis (CFA): The scale form that consisted of 19 items in total at the end of EFA analysis, an instruction to do the scale, and a Personal Information Form were added respectively and copied as hard copy and converted into an online form on Google Forms to gather information for CFA. The copied forms were delivered to the participants who had been married for at least a year and were voluntarily willing to participate in this study. The scale forms were filled in by 455 people as hard copies or online. The data gathered from 455 people were arranged in a way to include the participants who stated that they had experienced an incident affecting their marriage negatively as an answer to the open-ended question at the end of the Personal Information Form and exclude those who didn't state that they had experienced an incident affecting their marriage negatively. At the end of this step, data gathered from 247 participants were included in the study. As CFA is a method of analysis that is sensitive to sample, it is necessary to prepare the data for CFA after the data entry Erkuş, 2012; Tabachnick and Fidell, 2015, p. 617; (Tavşanc1l, 2010). In this line, first of all, data gathered from 247 participants were entered into SPSS 21.0 package program. Then data entry was checked to see if there was a false entry and it was seen there was no such case. Among 247 data, three of them were noticed to be missing data and excluded from the study. After excluding the missing data from the data set, the reverse items 10 and 15 were amended. After amending the points of the revere items, 11 data that were seen to be outliers were excluded from the data set. After that, there were 233 data to conduct CFA. While conducting CFA, SPSS 21.0 and LISREL package programs were used.

Creating the Final Form: The final form of MAIS was created at the end of the analyses.

\section{RESULTS}

\section{Explanatory Factor Analysis (EFA)}

The first step of developing MAIS was to conduct EFA to reveal the construct of the scale. First of all, Kaiser-Meyer-Olkin (KMO) and Barlett tests were carried out to identify if the data set gathered from the experimental test form of MAIS was appropriate to conduct factor analysis or not. The test results are given in Table 5:

\begin{tabular}{lcc}
\hline \multicolumn{3}{l}{ Table 5. Results of KMO and Barlett Tests } \\
\hline \multicolumn{2}{c}{ Keiser-Meyer-Olkin Measure of Sampling Adequacy } & 0,960 \\
\cline { 2 - 3 } Barlett Test for Sphericity & $\mathrm{X}^{2}$ & 9282,731 \\
\cline { 2 - 3 } & $\mathrm{Sd}$ & 861 \\
\hline
\end{tabular}

As is seen in Table 5, the KMO measure of sampling adequacy value was found to be 0,960 . This is above the acceptable value of 0,50 . A KMO value over 0,50 is acceptable; a value between $0,50-0,70$ is average; a value between $0,70-0,80$ is good, a value between $0,80-0,90$ is perfect, and a value over 0,90 is great 
(Cenry \& Kaiser, 1977; Kaiser, 1974). According to Ntoumanis (2001, p. 140.) and Pallant (2005), a KMO value over 0,60 is acceptable. Moreover, Barlett Test for Sphericity was found to be 9282,731 and is significant at a level of $0,001(X 2861=9282,731)$. Barlett Test for Sphericity should be significant to accept it appropriate for the given factor analysis (Ntoumanis, 2001, p. 140). According to this finding, the data gathered via the MAIS test form were appropriate for factor analysis.

After it was identified that the data gathered via the MAIS test form were appropriate to conduct factor analysis, EFA was done as to the 42 items included in the test form. Principal Axis Factoring, which is a factor extraction method, was adopted while doing this factor analysis. Moreover, the Promax rotation method, which is an oblique rotation method, was used as it was thought that the scale items were related to each other theoretically (Tabacknick and Fidell, 2015, p. 614, 630). At the end of the first EFA, it was seen that five factors were having an eigenvalue of over 1 and that the five factors explained \%58,583 of the variance. The items that were giving load to more than one factor and those whose difference between the factor loads were below,20, and then the items having a factor load below,32 were excluded before conducting the analysis once again. At the end of the EFA, a scale construct with 19 items and two factors was obtained. The findings as to the obtained scale construct are given in Table 6:

\begin{tabular}{|c|c|c|c|}
\hline \multicolumn{4}{|c|}{ Table 6. Findings as to the Obtained Scale Construct } \\
\hline Item No & Items & Factor 1 & Factor 2 \\
\hline 32 & $\begin{array}{l}\text { Bu olaydan sonra eşimle birbirimize karşı yabancılaştı̆ı̆ııı1 } \\
\text { hissediyorum. }\end{array}$ & ,840 & \\
\hline 36 & $\begin{array}{l}\text { Bu olaydan sonra eşimle bir daha asla eskisi gibi olamayacağımız1 } \\
\text { düşünüyorum. }\end{array}$ & ,813 & \\
\hline 30 & Yaşadığımız bu olayda eșim tarafından terk edilmiş gibi hissediyorum. & 807 & \\
\hline 38 & $\begin{array}{lllll}\text { Bu olaydan sonra eşimle paylaştığımız şeylerin azaldığını } \\
\text { hissediyorum. }\end{array}$ & ,791 & \\
\hline 33 & $\begin{array}{l}\text { Bu olaydan sonra ilisskimizde bir kısır döngüye girdiğimizi } \\
\text { düşünüyorum. }\end{array}$ & ,773 & \\
\hline 20 & $\begin{array}{l}\text { Bu olayın ardından evliliğimizin düzeleceğine dair umudumun } \\
\text { kalmadığını düşünüyorum. }\end{array}$ & ,749 & \\
\hline 37 & $\begin{array}{l}\text { Bu olaydan sonra eşimin hayatında önemli biri olduğumu } \\
\text { hissetmiyorum. }\end{array}$ & ,743 & \\
\hline 8 & Bu olaydan sonra, eşimin bana değer vermediğini düşünüyorum. & ,736 & \\
\hline 18 & $\begin{array}{l}\text { Bu olaydan sonra eşimle birbirimize karşı davranışlarımızın olumsuz } \\
\text { yönde değiştiğini hissediyorum. }\end{array}$ & ,683 & \\
\hline 26 & $\begin{array}{l}\text { Bu olaya rağmen, zor bir durumla karşılaştığımda eşimin benim } \\
\text { yanımda olacağından eminim. }\end{array}$ & ,683 & \\
\hline 34 & Bu olaya rağmen, eşim her ihtiyaç duyduğumda yanımdadır. & ,676 & \\
\hline 7 & Bu olaydan sonra eşimle daha az vakit geçiriyorum. & 663 & \\
\hline 24 & Bana bu olayı hatırlatan rüyalar görüyorum. & & ,876 \\
\hline 19 & $\begin{array}{l}\text { Gün içerisinde herhangi bir olay ya da nesne bana bu olay1 } \\
\text { hatırlatabiliyor. }\end{array}$ & & 805 \\
\hline 42 & Bu olay nedeniyle kendimi gergin ve tedirgin hissediyorum. & &, 732 \\
\hline 27 & Bu olay nedeniyle uyku problemleri yaşıyorum. & &, 715 \\
\hline 2 & $\begin{array}{l}\text { Bu olaydan sonra görünür bir neden yokken ağlama krizleri } \\
\text { yaşıyorum. }\end{array}$ & & ,688 \\
\hline 9 & Bu olaydan sonra sağlığımın bozulduğunu hissediyorum. & & ,654 \\
\hline 15 & Yaşadığımız bu olayı hatırlama ihtimalinden tedirgin oluyorum. & & ,643 \\
\hline & Eigenvalue & 9,255 & 2,381 \\
\hline & Explained Variance & 46,632 & 10,057 \\
\hline & Total Explained Variance & & 56,689 \\
\hline
\end{tabular}


As is seen in Table 6, it has been found out at the end of EFA analysis that the 19 items included in the scale are gathered under two factors; the eigenvalue of the first factor including 12 items is 9,255 and the eigenvalue of the second factor including seven items is 2,381 .

When the factor loads of the items in the scale are examined, it is seen that item factor loads vary between 0,643 and 0,876 . Item factor loads of items in a scale need to be 0,40 at least (DeVellis, 2003; Field, 2005). According to Tabacknick and Fidell (2015) as well as Comrey and Lee (1992), item factor loads should be over 0,32 . In this line, it can be said that item factor loads of the items included in the scale are at a good level.

The first factor of the scale, which is called "insecure attachment", explains \% 46,632 of the variance, whereas the second factor called "trauma" explains \%10,057 of the variance. It is seen that the total explained variance is $\% 56,689$.

\section{Correlations Between Factors}

After examining the scale construct via EFA and obtaining two factors in the end, relations between the factors were examined with the same sample group later on. In this direction, the Pearson correlation coefficient was calculated, and the correlation coefficient between the factors of insecure attachment and trauma was found to be 0,560 . According to this finding, it is seen that there is a statistically significant relation at a medium level between the factors of insecure attachment and trauma in the AIMS $(\mathrm{p}<0,01)$.

\section{Item Total Correlations}

After identifying the construct of the scale via EFA and calculating the correlations between factors, item-total correlations of the items included in the scale were examined to identify if the items can measure the expected quality or not. Item total correlation calculated for each item is given in Table 7:

\begin{tabular}{ccccc}
\hline \multicolumn{2}{l}{ Table 7. Item Total Correlations as to the Scale Items } & & \\
\hline Factors & Items & $\mathrm{X}_{\text {mean }}$ & $\mathrm{Sd}$ & Total Item Correlation \\
\hline Attachment & AIMS32 & 1,93 & 1,31 &, 802 \\
& AIMS36 & 1,82 & 1,21 &, 696 \\
& AIMS30 & 1,85 & 1,31 &, 738 \\
& AIMS38 & 2,04 & 1,33 &, 803 \\
& AIMS33 & 1,96 & 1,33 &, 652 \\
& AIMS20 & 1,45 &, 82 &, 635 \\
& AIMS37 & 1,93 & 1,36 &, 688 \\
& AIMS8 & 1,84 & 1,25 &, 805 \\
& AIMS18 & 2,19 & 1,33 &, 469 \\
& AIMS26 & 1,85 & 1,28 &, 452 \\
& AIMS34 & 1,90 & 1,23 &, 704 \\
\hline Trauma & AIMS7 & 1,97 & 1,32 &, 471 \\
& AIMS24 & 1,94 & 1,25 &, 628 \\
& AIMS19 & 2,43 & 1,40 &, 701 \\
& AIMS42 & 2,72 & 1,43 &, 574 \\
& AIMS27 & 2,16 & 1,38 &, 515 \\
& AIMS2 & 2,16 & 1,33 &, 603 \\
& AIMS9 & 2,48 & 1,42 &, 528 \\
\hline
\end{tabular}

As is seen in Table 7, item-total correlations of 19 items included in the scale, which were calculated to identify if the items can measure the expected quality or not, vary between $r=, 452$ and $r=, 805$. Item total 
correlations of the items falling under the factor of insecure attachment vary between $r=, 452$ and $r=, 805$, whereas item-total correlations of the items falling under the factor of trauma vary between $r=, 471$ and $r=, 628$. According to Ebel (1965), having an item-total correlation coefficient over $r=, 40$ means that the item is distinctive at a high level. According to Field (2005), it is necessary to have item test correlations at or over $r=30$. At this point, it can be stated that item-total correlation values of the items in this scale mean that the items are distinctive at a high level, namely, the items can measure the expected quality.

\section{Comparing the Means of Upper and Lower Groups of \%27}

To identify the distinctive power of the scale and 19 items in the scale obtained at the end of EFA, the differences between upper and lower groups of $\% 27$ were examined for the total scale and each item in the scale. Not only total scores but also independent samples t-test values for each item in the scale were calculated to examine the differences between these groups. Independent samples t-test results regarding the comparison of upper and lower groups of $\% 27$ for the total scale and each item are given in Table 8:

Table 8. Independent Samples t-Test Results for Upper and Lower Groups of \%27 for Total Score and Item Scores

\begin{tabular}{|c|c|c|c|c|c|c|}
\hline Items & & $\mathrm{N}$ & $\mathrm{X}_{\text {mean }}$ & $\mathrm{Sd}$ & $\mathrm{t}$ & $p$ \\
\hline \multirow[t]{2}{*}{$\mathrm{I} 32$} & Upper $\% 27$ & 77 & 3,62 & 1,11 & 20,28 &, 00 \\
\hline & Lower $\% 27$ & 77 & 1,03 & ,16 & & \\
\hline \multirow[t]{2}{*}{$\mathrm{I} 36$} & Upper $\% 27$ & 77 & 3,20 & 1,12 & 16,94 & , 00 \\
\hline & Lower $\% 27$ & 77 & 1,01 & ,11 & & \\
\hline \multirow[t]{2}{*}{$\mathrm{I30}$} & Upper\%27 & 77 & 3,36 & 1,40 & 14,61 & , 00 \\
\hline & Lower $\% 27$ & 77 & 1,03 &, 16 & & \\
\hline \multirow[t]{2}{*}{ I38 } & Upper $\% 27$ & 77 & 3,66 & 1,05 & 22,33 &, 00 \\
\hline & Lower $\% 27$ & 77 & 1,00 &, 00 & & \\
\hline \multirow[t]{2}{*}{ I33 } & Upper $\% 27$ & 77 & 3,65 & 1,12 & 20,53 &, 00 \\
\hline & Lower $\% 27$ & 77 & 1,01 & ,11 & & \\
\hline \multirow[t]{2}{*}{$\mathrm{I} 20$} & Upper $\% 27$ & 77 & 2,35 & 1,01 & 11,73 & ,00 \\
\hline & Lower $\% 27$ & 77 & 1,00 &, 00 & & \\
\hline \multirow[t]{2}{*}{ I37 } & Upper\%27 & 77 & 3,27 & 1,32 & 13,79 &, 00 \\
\hline & Lower $\% 27$ & 77 & 1,06 &, 47 & & \\
\hline \multirow[t]{2}{*}{18} & Upper\%27 & 77 & 3,10 & 1,30 & 13,61 &, 00 \\
\hline & Lower $\% 27$ & 77 & 1,05 & ,22 & & \\
\hline \multirow[t]{2}{*}{ I18 } & Upper $\% 27$ & 77 & 3,83 & 83 & 27,44 &, 00 \\
\hline & Lower $\% 27$ & 77 & 1,07 &, 30 & & \\
\hline \multirow[t]{2}{*}{$\mathrm{I} 26$} & Upper $\% 27$ & 77 & 2,87 & 1,41 & 8,09 & , 00 \\
\hline & Lower $\% 27$ & 77 & 1,31 & ,94 & & \\
\hline \multirow[t]{2}{*}{ I34 } & Upper $\% 27$ & 77 & 2,75 & 1,21 & 8,21 &, 00 \\
\hline & Lower $\% 27$ & 77 & 1,33 & ,94 & & \\
\hline \multirow[t]{2}{*}{ I7 } & Upper $\% 27$ & 77 & 3,44 & 1,20 & 17,39 &, 00 \\
\hline & Lower $\% 27$ & 77 & 1,03 & ,23 & & \\
\hline \multirow[t]{2}{*}{$\mathrm{I} 24$} & Upper\%27 & 77 & 2,74 & 1,37 & 10,48 & , 00 \\
\hline & Lower $\% 27$ & 77 & 1,07 & ,30 & & \\
\hline \multirow[t]{2}{*}{ I19 } & Upper $\% 27$ & 77 & 3,58 & 1,22 & 16,50 &, 00 \\
\hline & Lower $\% 27$ & 77 & 1,14 &, 45 & & \\
\hline \multirow[t]{2}{*}{$\mathrm{I} 42$} & Upper $\% 27$ & 77 & 4,07 & 1,00 & 20,16 &, 00 \\
\hline & Lower $\% 27$ & 77 & 1,31 & ,65 & & \\
\hline \multirow[t]{2}{*}{ I27 } & Upper $\% 27$ & 77 & 3,31 & 1,34 & 11,84 & ,00 \\
\hline & Lower $\% 27$ & 77 & 1,23 &, 76 & & \\
\hline \multirow[t]{2}{*}{$\mathrm{I} 2$} & Upper $\% 27$ & 77 & 3,03 & 1,41 & 10,55 &, 00 \\
\hline & Lower $\% 27$ & 77 & 1,22 & .50 & & \\
\hline
\end{tabular}




\begin{tabular}{lllllll}
\hline \hline \multicolumn{1}{c}{} & & & & & \\
\hline I9 & Upper $\% 27$ & 77 & 3,71 & 1,21 & 16,79 &, 00 \\
\hline & Lower $\% 27$ & 77 & 1,21 &, 50 & & \\
\hline I15 & Upper $\% 27$ & 77 & 3,55 & 1,37 & 11,74 &, 00 \\
\hline & Lower $\% 27$ & 77 & 1,39 &, 85 & & \\
\hline TOTAL & Upper $\% 27$ & 77 & 63,10 & 8,77 & 40,76 &, 00 \\
\hline & Lower $\% 27$ & 77 & 21,49 & 1,80 & & \\
\hline
\end{tabular}

As is clear in Table 8, upper and lower group values show a statistically significant difference in favor of the upper group for each item. In other words, upper group values are higher than lower group values at a statistically significant level for each item. Moreover, upper and lower group values differ at a statistically significant level in favor of the upper group for scale total values. According to this, it can be said that each item in the scale and the whole scale is distinctive.

\section{Criterion-Related Validity}

RAS and MDS were implemented with the same sample group to prove criterion validity. Pearson Product-Moment Correlation Coefficient values regarding the relation between MAIS, and RAS, and MDS are given in Table 9:

\section{Table 9. The Relation Between MAIS, and RAS, and MDS}

\begin{tabular}{|c|c|c|c|c|c|}
\hline & Attachment & Trauma & MAIS Total & RAS_Total & MDS_Total \\
\hline Insecure Attachment & 1 & & & & \\
\hline Trauma & ,560* & 1 & & & \\
\hline MAIS**_Total & ,933* & ,821* & 1 & & \\
\hline RAS***_Total &,$- 767 *$ &,$- 403^{*}$ &,$- 704 *$ & 1 & \\
\hline MDS****_Total & ,749* & ,363* & ,674* &,$- 886^{*}$ & 1 \\
\hline
\end{tabular}

As is seen in Table 9 about the Pearson Product-Moment Correlation Coefficient values calculated to prove criterion validity, there is a statistically significant relationship in the negative direction at a high level between the factor of insecure attachment in MAIS and RAS total values $(r=-0,767, p<0,01)$, whereas there is a statistically significant relationship in the positive direction at a high level between the factor of insecure attachment in MAIS and MDS total values $(r=0,749, \mathrm{p}<0,01)$. The factor of trauma in MAIS has a statistically significant relationship in the negative direction at a medium level with RAS total values $(r=-0,403, p<0,01)$, whereas it has a statistically significant relationship in the positive direction at a medium level with MDS total value $(r=0,363, p<0,01)$. It is seen that there is a statistically significant relationship in the negative direction at a high level between MAIS total scores and RAS total scores $(r=-$ $0,704, \mathrm{p}<0,01)$ there is a statistically significant relationship in the positive direction at a medium level between MAIS total scores and MDS total scores $(\mathrm{r}=0,674, \mathrm{p}<0,01)$. When the correlation values are considered, it can be stated that the relation between scale scores identified to prove criterion validity and MAIS factor total scores are as expected and so criterion validity is ensured.

\section{Reliability of Scale}

Scale factor total scores and Cronbach alpha reliability coefficients regarding scale total scores were calculated to identify if MAIS is a reliable scale or not. The findings as to MAIS factor total scores and Cronbach alpha reliability coefficients regarding scale total scores are given in Table 10:

\begin{tabular}{cccc}
\hline \multicolumn{4}{l}{ Table 10. Cronbach Alpha Reliability Coefficients Regarding MAIS and its Factors } \\
\hline & $\mathrm{N}$ & Number of Items & Cronbach Alfa \\
\hline Insecure Attachment & 287 & 12 &, 939 \\
\hline
\end{tabular}




\begin{tabular}{cccc}
\hline & & & \\
\hline Trauma & 287 & 7 &, 882 \\
\hline MAIS*_Total & 287 & 19 &, 937 \\
\hline
\end{tabular}

*Marital Attachment Injuries Scale

As is seen in Table 10, the reliability coefficient of the MAIS factor of insecure attachment is Cr $\alpha=0,939$; the reliability coefficient of the factor of trauma is $\operatorname{Cr} \alpha=0,882$, and the reliability coefficient of MAIS is $\mathrm{Cr} \alpha=0,937$. Cronbach alpha reliability coefficient of a scale is expected to be over 0,70 to accept it to be a reliable measurement tool (DeVellis, 2003; Nunally, 1978). Therefore, MAIS and its factors can be said to be reliable.

\section{Confirmatory Factor Analysis (CFA)}

CFA was conducted with a different sample group to examine the construct validity of the two factors obtained at the end of EFA and 19 items. In this direction, the data obtained from this sample group were used and-square/Degree of freedom ( $(2 / \mathrm{df})$, Root Mean Square Error of Approximation (RMSEA), Goodness of Fit Index (GFI), Adjusted Goodness of Fit Index (AGFI), Normed Fit Index (NFI) and Comparative Fit Index (CFI) values were considered as model goodness of fit index.

Before conducting CFA, the data and item score distributions were examined if they were appropriate to conduct CFA. In this direction, item number 8 was excluded from the scale as it was seen to be an outlier. Path diagram regarding the first CFA (Figure 2) carried out with the remaining 18 items and goodness of fit index (Table 11) are given below:

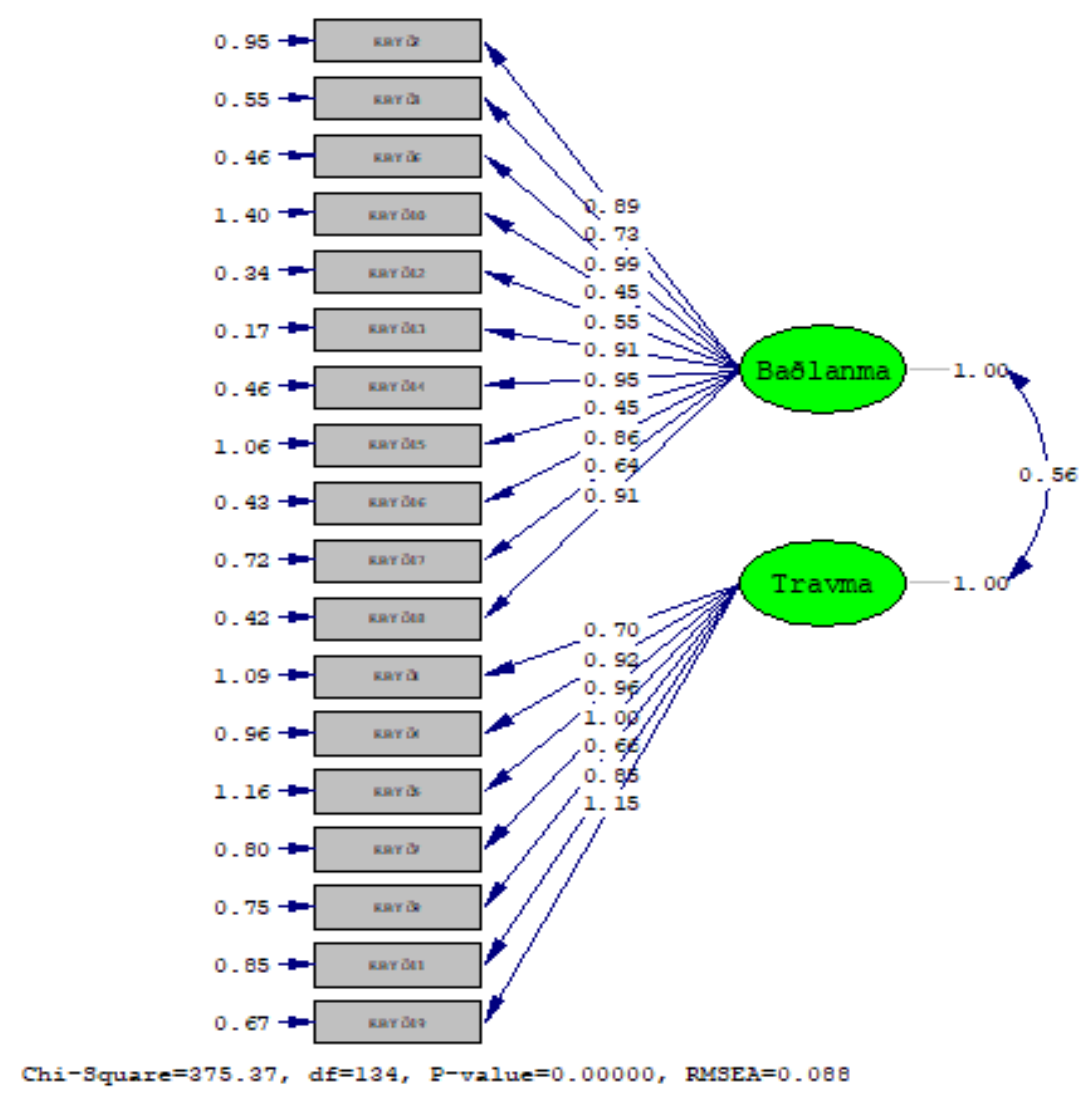

Figure 2. Path Diagram of the First CFA Regarding 18 items and 2 factors 
Table 11. The goodness of Fit Indexes Obtained at the End of the First CFA Regarding 18 Items and 2 Factors

\begin{tabular}{ccccccc}
\hline Model & $\chi 2 / \mathrm{df}$ & RMS & GFI & AGFA & NFI & CFI \\
\hline 18 Items and 2 Factors & $375,7 / 134=2,80$ &, 088 &, 85 &, 81 &, 93 &, 95 \\
\hline
\end{tabular}

As is seen in Figure 2 and Table 11, it is seen that acceptable values for the goodness of fit indexes obtained at the end of the first CFA could not be ensured (Marcoulides \& Schumacher, 2001). Suggestions for modifications and the items for which modifications were suggested were examined. A modification was suggested for two items (10 -15), and it was seen that these two items had a close meaning, so item 15 was removed from the scale as its factor load was lower than that of item 10. Confirmatory factor analysis was conducted again after removing item 15. Path diagram regarding the CFA (Figure 3) and goodness of fit index (Table 12) are given below:

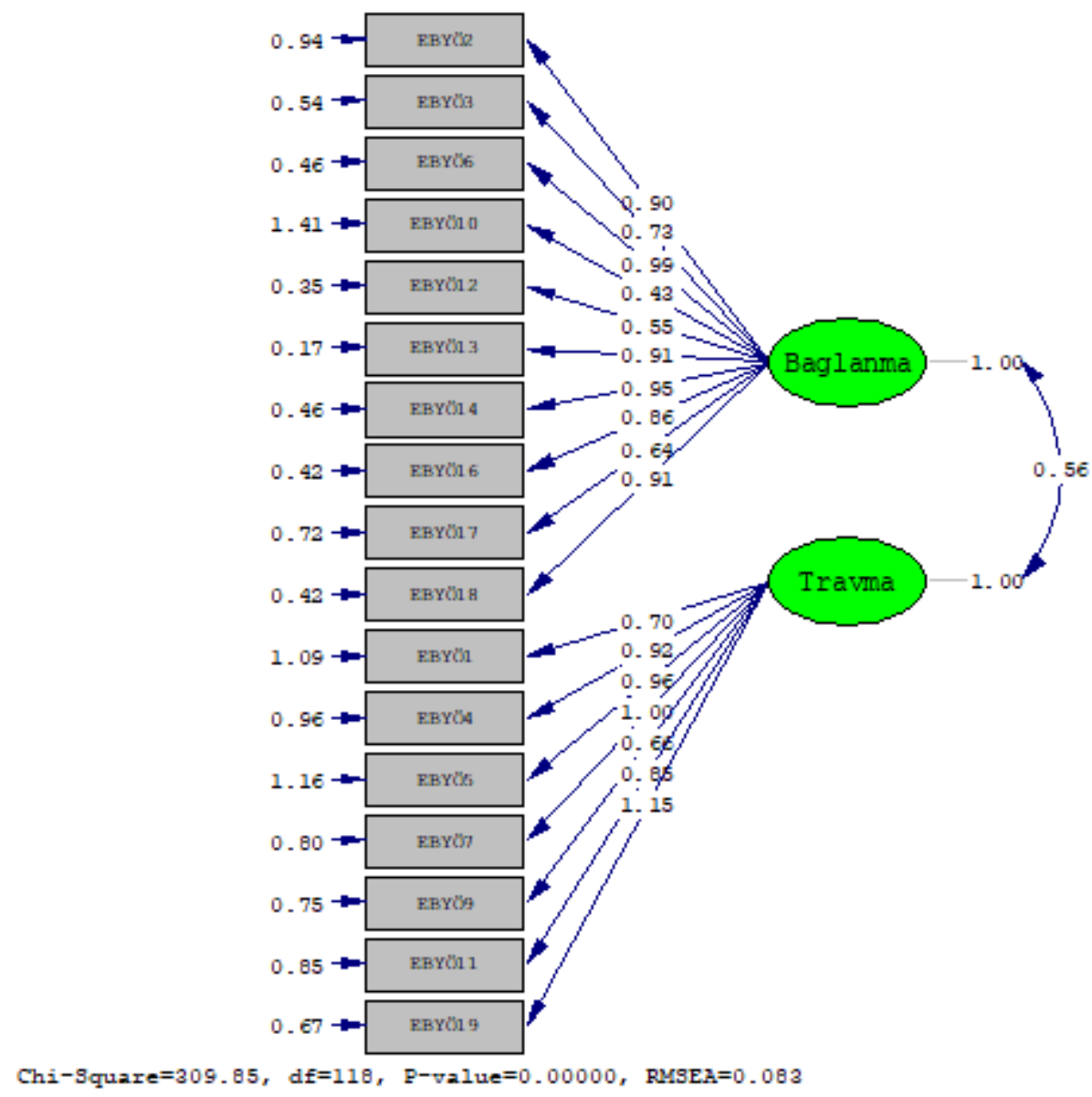

Figure 3. 2. CFA Path Diagram

\begin{tabular}{ccccccc}
\hline \multicolumn{1}{l}{ Table 12. 2. CFA Goodness of Fit Indexes } \\
\hline Model & $\chi 2 / \mathrm{df}$ & RMSEA & GFI & AGFI & NFI & CFI \\
\hline 17 Items and 2 Factors & $309,85 / 116=2,67$ &, 083 &, 87 &, 83 &, 94 &, 96 \\
\hline
\end{tabular}

As is seen in Figure 3 and Table 12, the goodness of fit indexes obtained at the end of the second CFA is not between the acceptable values (Marcoulides \& Schumacher, 2001). Suggestions for modifications and the items for which modifications were suggested were examined. A modification was suggested for two items and it was seen that these two items had close meanings $(14-16)$. However, it was decided that these two items should be included in the scale in theoretical terms, so error covariance was added 
between these two items, and CFA was conducted once again. It was seen that the goodness of fit indexes of the model got better. Path diagram regarding the CFA after the modification (Figure 4) and goodness of fit index (Table 13) are given below:

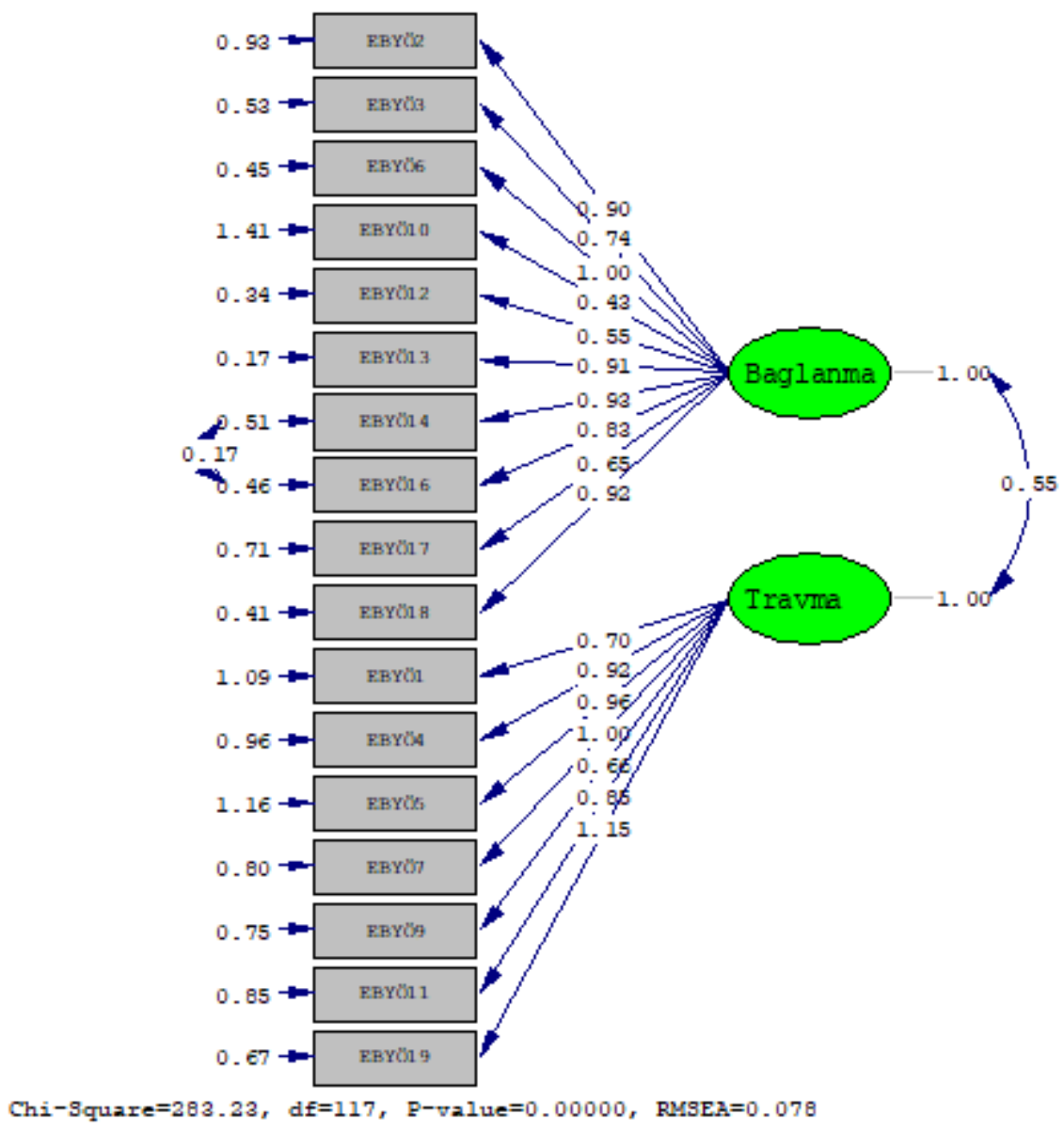

Figure 4. Final CFA Path Diagram

Table 13. Last DFA Goodness of Fit Indexes

\begin{tabular}{ccccccc}
\hline Model & $\chi 2 / \mathrm{df}$ & RMSEA & GFI & AGFI & NFI & CFI \\
\hline 17 Items and 2 Factors & $283,23 / 117=2,42$ &, 078 &, 88 &, 84 &, 94 &, 96 \\
\hline
\end{tabular}

When Figure 4 and Table 13 are examined, it is clear that the goodness of fit indexes obtained at the end of the third CFA were between the acceptable values $(\chi 2 / \mathrm{df}=2,42 ; \mathrm{RMSEA}=0,078 ; \mathrm{GFI}=0,88$; AGFI $=0,84 ; \mathrm{NFI}=0,94 ; \mathrm{CFI}=0,96$ ) (Marcoulides \& Schumacher, 2001). Therefore, it can be stated that the construct validity of the scale was ensured with 17 items and two factors.

\section{DISCUSSION}

This study aims at developing a valid and reliable measurement tool to identify the level of attachment injuries of married individuals. In this light, first of all, EFA was conducted to reveal the construct of MAIS. As a result, MAIS having two factors of "insecure attachment" and "trauma" and 17 items in total were developed depending on the results of the analysis. The scale is a 5-point Likert scale (1-Strongly disagree, 5-Strongly agree). The lowest score to be obtained on the scale is 17 while the highest score can be 85 . Having a high score means that the individual has a high level of attachment injuries. 
Explanatory factor analysis and confirmatory factor analysis were conducted to test the construct validity of MAIS. Explanatory factor analysis revealed that the scale has a two-factor construct and the factors are "insecure attachment" and "trauma." Confirmatory factor analysis confirmed the two-dimensional model of the scale and revealed that the model has an acceptable goodness of fit index (Marcoulides \& Schumacher, 2001). It was found out that there is a statistically significant relationship at a medium level between the factors of the scale, correlation coefficients between the items and total scores are at an acceptable level, there is a statistically significant relationship between upper and lower groups of $\% 27$ in favor of upper groups, which means that the items are distinctive at a very high level. Within the framework of the validity studies, the relations between MAIS total scores and its factors on one side and RAS and MDS on the other side were examined to test the criterion-related validity of the scale. Correlation coefficients were calculated with an expectation that MAIS total scores and its factors would be related to RAS at a statistically significant level in the negative direction and MDS in the positive direction. As expected, there is a statistically significant relationship in the negative direction at a high level between RAS and the dimension of insecure attachment of MAIS, a statistically significant relationship in the negative direction at a medium level between RAS and the dimension of the trauma of MAIS, and a statistically significant relation in the negative direction at a high level between MAIS total score and RAS. Similarly, in line with the expectations, it was found out that MDS was related to the factor of insecure attachment of MAIS in the positive direction at a statistically significant high level, to the factor of the trauma of MAIS in the positive direction at a statistically significant medium, and the total points of MAIS in the positive direction at a medium level. Based on these findings, the measurement tool can be said to ensure criterion-related validity.

The reliability of MAIS was tested via total item correlations as well as Cronbach alpha coefficients regarding the total scores and dimensions. Item total correlations coefficient, which was carried out to see if the 17 items in MAIS could measure the expected quality or not, was found to be 90, which is an acceptable value (Ebel, 1965; Field, 2005). Also, Cronbach alpha coefficients regarding MAIS total scores and the dimensions of insecure attachment and trauma were analyzed to prove reliability. In this direction, it was seen that Cronbach alpha coefficients regarding the dimensions of MAIS and its total scores are between acceptable values (DeVellis, 2003; Nunally, 1978).

After ensuring that MAIS is a valid and reliable tool at the end of analyses conducted to prove reliability and validity, the explained variance of MAIS was calculated as the last step. It was seen the explained variance values for the dimension of insecure attachment, the dimension of trauma, and MAIS total scores are between acceptable values (Scherer, et al., 1988).

\section{Results and Recommendations}

Consequently, a valid and reliable measurement tool having two dimensions, which are called "insecure attachment" and "trauma", and 17 items in total to identify the level of attachment injuries of married individuals was obtained in this study.

This study has some limitations. This study is limited to the people who volunteered to participate in this study and to whom the researcher was able to reach. Validity and reliability values of the Marital Attachment Injuries Scale can be tested with different participant groups. The scale obtained within the framework of this study aims at identifying the level of attachment injuries of only married individuals. However, the concept of attachment injury is defined for all individuals having a romantic relationship. 
In that sense, a new scale for individuals having a romantic relationship can be developed or the validity and reliability of this scale can be analyzed with individuals having a romantic relationship. There aren't any quantitative studies about the concept of attachment injuries. They aren't known which variables correlate attachment injuries, which variables are caused the attachment injuries, who experience attachment injuries etc. In this direction. This scale can be used to carry out studies with different study groups and consider different variables, and so the variables regarding attachment injuries can be revealed. 


\section{REFERENCES}

Cerny, B. A. \& Kaiser, H. F. (1977). A study of a measure of sampling adequacy for factor-analytic correlation matrices. Multivariate Behavioral Research, 12(1), 43-47. https://doi.org/10.1207/s15327906mbr1201_3

Comrey, A. L. \& Lee, H. B. (1992). Interpretation and application of factor analytic results. In A. L. Comrey, \& H. B. Lee (Eds.), The first course is in factor analysis (p. 2). Hillsdale, NJ: Lawrence Erlbaum Associates.

Curun, F. (2001). The effects of sexism and sex role orientaion on romantic relationship satisfaction. (Unpublished master dissertation). Middle East Technical University.

Çelik, E. (2013). Adaptation of Marital Disaffection Scale To Turkish: Study of Validity and Reliability. Electronic Turkish Studies. 12(8), 249-261. http://dx.doi.org/10.7827/TurkishStudies.5663

Devellis, R. F. (2003). Scale Development: Theory and Applications. Second Edition. Thousand Oaks: Sage Publications.

Ebel, R. L. (1965). Measuring educational achievement. Englewoodcliffs.

Erkuş, A. (2011). Scientific research process for behavioral sciences (3.Bask1). Ankara: Seçkin.

Erkuş, A. (2012). Psychological measurement and scale development - I. Ankara: Seçkin.

Field, A. (2005). Discovering statistics using SPSS. London: SAGE.

Frankel, J. R., Wallen, N. E. \& Hyun, HH (2012). How to design and evaluate research in education. New York: McGrawHill.

Halchuk, R. E., Makinen, J. A. \& Johnson, S. M. (2010). Resolving attachment injuries in couples using emotionally focused therapy: A three-year follow-up. Journal Of Couple \& Relationship Therapy, 9(1), 31-47. https://doi.org/10.1080/15332690903473069

Hendrick, S. S. (1988). A generic measure of relationship satisfaction. Journal of Marriage and The Family, 50(1), 9398. https://doi/10.2307/352430

Johnson, S. M. (1996). The practice of emotionally focused marital therapy: creating connection. Brunner/Mazel.

Johnson, S. M., Makinen, J. A. \& Millikin, J. W. (2001). Attachment injuries in couple relationships: a new perspective an impasses in couples therapy. Journal of Marital and Family Therapy, 27(2), 145-155. https://doi.org/10.1111/j.1752-0606.2001.tb01152.x

Kaiser, H. F. (1974). An Index of Factorial Simplicity. Psychometrika, 39(1), 31-36. https://link.springer.com/content/pdf/10.1007/BF02291575.pdf

Karasar, N. (2009) scientific research method. Ankara: Nobel.

Kayser, K. (1996). The marital disaffection scale: An inventory for assessing emotional estrangement in marriage. American Joumal of Family Therapy, 24(1), 83-88. https://doi.org/10.1080/01926189508251019

Makinen, J. A. (2004). Resolving attachment injuries in couples: relating process to outcome. (Doctoral Dissertation). University of Ottawa.

Makinen, J. A. \& Johnson, S. M. (2006). Resolving attachment injuries in couples using emotionally focused therapy: steps toward forgiveness and reconciliation. Journal Of Consulting and Clinical Psychology, 74(6), 10551064. https://doi.org/10.1037/0022-006X.74.6.1055

Marcoulides, G. \& Schumacher, R. (2001). New developments and techniques instructural equation modeling. New York: Lawrence Erlbaum Associates.

Millikin, J. W. (2000). Resolving attachment injuries in couples using emotionally focused therapy: a process study. (Doctoral Dissertation). Virginia Polytechnic Institute and State University

Naaman, S., Pappas, J. D., Makinen, J., Zuccarini, D. \& Johnson-Douglas, S. (2005). Treating attachment injured couples with emotionally focused therapy: a case study approach. Psycbiatry: Interpersonal and Biological Processes,68(1), 55-77. https://doi.org/10.1521/psyc.68.1.55.64183 
Ntoumanis, N. (2001). A self-determination approach to the understanding of motivation in physical education. British Journal of Educational Psychology, 71(2), 225-242. https://doi.org/10.1348/000709901158497

Nunnally, J. (1978). Psychometric methods. New York: McGraw-Hill.

Pallant, J. (2005). SPSS survival manual: A step-by-step guide to data analysis using SPSS for windows. New York: McGrawHill.

Pelling, C. (2003). Women's lives experiences of attachment injury within their couple relationships. (Doctoral Dissertation). Simon Fraser University.

Pelling, C. \& Arvay-Buchanan, M. (2007). Experiences of attachment injury in heterosexual couple relationships. Canadian Journal of Counselling and Psychotherapy / Revuecanadienne De Counseling Et De Psychothérapie, 38(4), 289-303. https:/ / files.eric.ed.gov/fulltext/EJ719915.pdf

Scherer, R. F., Luther, D. C., Wiebe, F. A. \& Adams, J. S. (1988). Dimensionality of coping: factor stability using the ways of coping questionnaire. Psychological Reports, 62(3), 763-770. https://doi.org/10.2466\%2Fpr0.1988.62.3.763

Tabacknick, B. G. \& Fidell, L.S. (2015). Use of multivariate statistics (M.Baloğlu, Tr. Ed.). Ankara: Nobel.

Tavşanc1l, E. (2010). Measuring attitudes and data analysis with SPSS. Ankara: Nobel.

Terzi, S. \& Özbay, Y. (2016). Development of attachment injuries scale in romantic relationships. Education and Society in the 21st Century, 5(13), 169-185. https://toad.halileksi.net/sites/default/files/pdf/romantikiliskilerde-baglanma-yaralanmalari-olcegi-toad.pdf 


\section{About Authors}

Sare Terzi İlhan. Undergraduate: Ankara University, Guidance and Psychological Counseling; Graduate: Gazi University Guidance and Psychological Counseling; Doctorate: Gazi University, Guidance and Psychological Counseling. She is currently working at Amasya University. Fields of studies are romantic relationships, marriage and family counseling, positive psychology.

Şerife Iş1k. Undergraduate: Gazi University, Guidance and Psychological Counseling; Graduate: Gazi University Guidance and Psychological Counseling; Doctorate: Gazi University, Guidance and Psychological Counseling. She is currently working at Gazi University. Fields of studies are positive psychology, school counseling, resilience.

\section{Author Contributions}

This study was produced from the Sare Terzi İlhan's doctoral thesis. Şerife Işık was the thesis advisor. This study was carried out by Sare Terzi Ilhan, under the consultancy of Şerife Işı1k.

\section{Conflict of Interest}

It has been reported by the authors that there is no conflict of interest.

\section{Funding}

No funding support was received.

\section{Note}

This article was produced from Sare Terzi İlhan's doctoral thesis entitled "The mediating role of attachment injuries in the relationship between personality traits and couple adjustment of the individiuals have a child with special needs".

\section{Ethical Statement}

This research was completed in line with the Helsinki Declaration. In line with this, the study was investigated and permitted by Amasya University Scientific Research and Ethical Review Board. Additionally, data tools in the study were only distributed to volunteer participants. All participants provided informed consent. Additionally, participants were informed that they could withdraw from the study at any time during data collection.

Ethics Committee Name: Amasya University Scientific Research and Ethical Review Board.

Approval Date: 15/09/2020.

Approval Document Number: 19642/15.09.2020 